\section{Effect of Nitrogen-fixing Microorganisms and Amino Acid-based Biostimulants on Perennial Ryegrass}

\author{
Verónica De Luca ${ }^{1}$, Diego Gómez de Barreda ${ }^{1}$, Antonio Lidón ${ }^{2}$, \\ and Cristina Lull ${ }^{2}$
}

AdDITIONAL INDEX WORDs. Lolium perenne, nitrogen mineral fertilization, nutritional stress, rhizobacteria, turfgrass

SuMmary. Due to restrictions on pesticide and nitrogen use in high-input European agricultural systems, many of the biostimulants used in horticulture are being incorporated into turfgrass management programs - although often with little understanding. A set of experiments was carried out on perennial ryegrass (Lolium perenne) cultivated in pots in a greenhouse in 2013 and 2014 to test the effect of three biostimulants: two composed of nitrifying bacteria (B1 and B2), and the other a mixture of amino acids, polysaccharides, nitrogen, and micronutrients (B3). Apart from the biostimulant treatment, nutritional stress was incorporated into the study to demonstrate if biostimulants could temporarily replace the fertilization role and so lessen the environmental impact. Turfgrass treated with Bl resulted in an increase in quality compared with untreated turf, and the positive effect lasted 2 and 3 months in 2013 and 2014, respectively. Additionally, an extended benefit was observed when the BI interval application was longer, even temporarily replacing fertilization when applied on stressed turfgrass. The B2 produced similar results to B1, the effect was longer, and the turf exhibited a darker color-although it caused phytotoxicity at the tip of the leaves. The B3 led to a beneficial effect on turfgrass, especially under nutritional stress; it showed a better quality, darker green color, and more growth and yield than untreated turf (despite adding less nitrogen than during either mineral fertilizer treatment). Overall results show that the tested biostimulants increase turfgrass quality even when inducing a nutritional stress.

$\mathrm{T}$ he most important nutrient for optimal plant growth is nitrogen $(\mathrm{N})$, but it is known that in intensive agricultural systems there is an environmental risk caused by inadequate management of $\mathrm{N}$ fertilization (Neeteson and Carton, 2001). Processes such as nitrate leaching and nitrous oxide emissions produce major environmental problems in water and the atmosphere (Guo et al., 2010; Ramos et al., 2002). On the

Received for publication 26 Mar. 2019. Accepted for publication 19 Feb. 2020

Published online 19 March 2020

${ }^{1}$ Plant Production Department, Universitat Politècnica de València, Camí de Vera s/n, 46022 Valencia, Spain

${ }^{2}$ Research Group in Forest Science and Technology (Re-ForeST), Research Institute of Water and Environmental Engineering (IIAMA), Universitat Politècnica de València, Camí de Vera s/n, 46022 Valencia, Spain

We would like to acknowledge Semillas Dalmau SL for seeds and Biotecnología del Mediterráneo SL for providing biostimulants.

D.G.B. is the corresponding author. E-mail: diegode@ btc.upv.es.

This is an open access article distributed under the CC BY-NC-ND license (https://creativecommons.org/ licenses/by-nc-nd/4.0/).

https://doi.org/10.21273/HORTTECH04236-19 other hand, other agricultural inputs such as pesticides can be harmful to nontarget organisms and can produce adverse effects on human health and the environment if used negligently. Regulations set by the European Union for the sustainable use of fertilizers and pesticides to reduce risks and to lessen the impact on human health and the environment (European Union, 1991, 2009, respectively) may increase the use of biostimulants as replacements for many ingredients that are being rejected for use in turfgrass. However, the term "biostimulant" is wide and loosely defined (Mueller and Kussow, 2005). The term includes an array of products, from seaweed to cultured living microorganisms and various natural chemicals and compounds (du Jardin, 2015; Karnok, 2000; Van Oosten et al., 2017).

Calvo et al. (2014) extensively reported on the agricultural uses of plant biostimulants. Specifically, biostimulants have already been positively tested in horticulture. Battacharyya et al. (2015) reviewed the effects of seaweed extracts on vegetable, fruit, and ornamental crops-including tall fescue (Festuca arundinacea) and creeping bentgrass (Agrostisstolonifera) - and concluded that there are a number of questions that still need to be addressed for the better use of seaweed resources and their extracts in horticultural crops.

Another review of the effect of biostimulants based on humic and fulvic acids on 30 horticulture crops concluded that the use of such biostimulants in horticultural crops is a key sustainable technology that can make cropping systems more productive, efficient, and less harmful to the environment (Canellas et al., 2015). Protein hydrolysates (a mixture of peptides and amino acids) have also been positively used as biostimulants for making horticultural crops more sustainable (Colla et al., 2015, 2017).

Finally, the use of soil microorganisms (bacteria or fungus) as biostimulants for increasing the nutrient and water-use efficiency of horticultural crops has also been successfully tested (Acikgoz et al., 2016; LópezBucio, et al., 2015; Rouphael et al., 2015; Ruzzi and Aroca, 2015; Sahin and Turan, 2013). Yadav et al. (2017) reported that the use of plant growth promoting bacteria (Azotobacter, Bacillus, and Pseudomonas, and other genera) may prove useful in developing strategies to facilitate plant growth under normal conditions, as well as under abiotic stress. Another area of potential enhancement of $\mathrm{N}$ nutrition in turfgrasses and adaptation to environmental stress involves associative $\mathrm{N}$ fixation by bacteria and mycorrhizal fungi (Duncan

\begin{tabular}{llll}
\hline $\begin{array}{l}\text { Units } \\
\text { To convert U.S. to } \\
\text { SI, multiply by }\end{array}$ & U.S. unit & SI unit & $\begin{array}{l}\text { To convert SI to } \\
\text { U.S., multiply by }\end{array}$ \\
\hline 29.5735 & fl oz & $\mathrm{mL}$ & 0.0338 \\
2.54 & inch $(\mathrm{es})$ & $\mathrm{cm}$ & 0.3937 \\
25.4 & inch $(\mathrm{es})$ & $\mathrm{mm}$ & 0.0394 \\
28.3495 & $\mathrm{oz}$ & $\mathrm{g}$ & 0.0353 \\
33.9057 & $\mathrm{oz} / \mathrm{yard}^{2}$ & $\mathrm{~g} \cdot \mathrm{m}^{-2}$ & 0.0295 \\
$\left({ }^{\circ} \mathrm{F}-32\right) \div 1.8$ & ${ }^{\circ} \mathrm{F}$ & ${ }^{\circ} \mathrm{C}$ & $\left({ }^{\circ} \mathrm{C} \times 1.8\right)+32$
\end{tabular}


and Carrow, 1999). Contributing to other positive roles, Azotobacter vinelandii, for example, can be used as soil contaminant detoxification bacteria (Ehaliotis et al., 1999).

Due to the success of biostimulants in vegetable and fruit crops, the biostimulant industry is focusing on turfgrass species, as there is a considerable business opportunity due to acreage and pesticide reduction regulations in this sector. However, many biostimulants marketed for turfgrass include mineral fertilizers that mask the effect of biostimulants on turfgrass, and which together with the large number of available products is making the use of biostimulants confusing for scientists, greenskeepers, and householders.

One of the most important turfgrass species in the temperate regions of the world is perennial ryegrass (Lolium perenne). This grass is suitable for home lawns, parks, cemeteries, roadsides, golf courses, and athletic fields (Wu et al., 2005). Perennial ryegrass is a cool-season turfgrass species, and its growth often is limited by high temperatures during summer months in warm climates (Jiang and Huang, 2001). A perennial ryegrass stand stressed by heat and/or other abiotic factors is more likely to be infected by diverse microorganisms, and the lack of pesticides is leading groundskeepers to apply biostimulants with little knowledge of their mechanism of action or how to integrate application procedures with other management practices (above all mowing and irrigation).

Little research has been conducted on the effect of biostimulants on perennial ryegrass. Kauffman et al. 2007 demonstrated that amino acid containing biostimulants when applied sequentially to perennial ryegrass foliage could positively affect turfgrass heat stress tolerance. Botta (2013) reported that an amino acidbased biostimulant applied on heatstressed perennial ryegrass showed superior photosynthetic efficiency and maintained higher levels of chlorophylls and carotenoids. Another amino acid (gamma aminobutyric acid) was foliar applied on drought-stressed perennial ryegrass, demonstrating that it was effective in mitigating the physiological response of drought stress damage (Krishnan et al., 2013). Acikgoz et al. (2016) conducted a study on perennial ryegrass and tall fescue that resulted in an increase of color ratings and clipping yields when treated with plant growth-promoting rhizobacteria. Several studies have been performed on perennial ryegrass for salt tolerance enhancement by applying biostimulants: $\mathrm{Hu}$ et al. 2012 found glycine betaine treatments useful in this type of stress and Sun et al. (2015) and Wu et al. (2017) suggested that a 24epibrassinolide treatment (a plant hormone) might improve perennial ryegrass salt tolerance.

Biostimulants have also been tested on other important turfgrass species. Elliot and Prevatte (1996) reported no positive effects for seaweed extracts on hybrid bermudagrass (Cynodon dactylon $\times$ C. transvaalensis) growth or quality. In tall fescue, seaweed extracts improved post-transplant rooting and quality of tall fescue sod (Zhang et al., 2003a). In creeping bentgrass, Aamlid et al. (2017) reported a faster growin on plots receiving amino acidbased biostimulants than on plots receiving mineral fertilizers. Xu and Huang (2010) reported improved turfgrass quality with sea plant extracts and microorganisms. However, a previous experiment (Aamlid and Hanslin, 2009) indicated that, on average, none of the tested biostimulants caused significant improvements in the overall impression of turfgrass [creeping bentgrass, perennial ryegrass, and kentucky bluegrass (Poa pratensis)] compared with control mineral fertilizer treatments. Only few improvements in foliar $\mathrm{N}$ uptake were reported by Stiegler et al. (2013) when single amino acid-based biostimulants were applied and compared with mineral fertilizers on creeping bentgrass. These last authors also reported that glycine was better absorbed than potassium nitrate, but none of the studied amino acid-based biostimulants exceeded urea $\mathrm{N}$ absorption. Another negative effect on creeping bentgrass due to a microbial inoculant biostimulant application was a delay in germination (Butler et al., 2007) or a $\mathrm{N}$ leaching increase when establishing a new golf green (Butler et al., 2012). Zhang et al. (2003b) and Zhang and Ervin (2008) reported that seaweed extracts and humic substances may be beneficial supplements for reducing standard fertilizer and fungicide inputs, while maintaining adequate health for creeping bentgrass. Zhang et al. (2013b) indicated a positive role for foliar amino acids in creeping bentgrass $\mathrm{N}$ summer fertilization programs.

Hence there is a need to improve our understanding of the function of biostimulants so that the efficacy of these materials can be improved and industrial processes can be optimized (Brown and Saa, 2015). The main research trend dealing with biostimulants on turfgrass science is in demonstrating that biostimulants are useful when applied before stress situations (heat, drought, disease, and nutrition) to reduce polluting agricultural inputs such as fertilizers and pesticides. A priority for many turfgrass managers is to maintain highquality turfgrass while minimizing their environmental risk.

The objective of our research was to test three commercial biostimulants on perennial ryegrass in greenhouse conditions considering two hypotheses: 1) the biostimulants increase turfgrass quality, and 2) the use of these biostimulants under nutritional stress reduces mineral fertilization in a turfgrass fertilization program.

\section{Materials and methods}

The effect of the biostimulants was tested on 'Esquire' perennial ryegrass in greenhouse pot studies during 2 consecutive years.

EXPERIMENTAL DESIGN. In 2013 (Apr. to Oct.), the biostimulants Azobio (B1), Rizobacter (B2), and Rizosan Eco (B3) (all manufactured by Biotecnología del Mediterráneo, Valencia, Spain) were tested, and the experiments were repeated in the same period of 2014. The nutritional stress factor was tested in addition to the biostimulant treatment factor. Two minor studies were performed with $\mathrm{B} 1$ and $\mathrm{B} 2$ biostimulants in 2014 to obtain more information on application intervals and dose response, respectively. The complete study was made up of eight randomized complete block design experiments with two factors: biostimulant treatment (treated or untreated) and nutritional stress (conventional fertilization or low fertilization); and four replicates.

Biostimulants. All tested biostimulants are already being commercialized for high-input vegetable production. The biostimulant $\mathrm{Bl}$ is 
Table 1. Repeated measures analysis of variance of perennial ryegrass treated twice in a 2 -week interval with the biostimulant 1 [B1 (Azobio; Biotecnología del Mediterráneo)] at $5.4 \mathrm{~mL}(0.18 \mathrm{fl} \mathrm{oz})$ per pot in 2013 and 2014.

\begin{tabular}{|c|c|c|c|c|c|c|c|c|}
\hline \multirow[b]{2}{*}{ B1 } & \multicolumn{4}{|c|}{2013} & \multicolumn{4}{|c|}{2014} \\
\hline & Turf quality & Turf color & Dry wt & Growth & Turf quality & Turf color & Dry wt & Growth \\
\hline Treatment & $0.04^{\mathrm{z}}$ & $<0.01$ & 0.67 & 0.46 & $<0.01$ & $<0.01$ & $<0.01$ & $<0.01$ \\
\hline Nutritional stress & 0.08 & 0.06 & 0.05 & 0.01 & $<0.01$ & $<0.01$ & $<0.01$ & $<0.01$ \\
\hline Time & $<0.01$ & $<0.01$ & $<0.01$ & $<0.01$ & $<0.01$ & $<0.01$ & $<0.01$ & $<0.01$ \\
\hline Treatment $\times$ nutritional stress & 0.23 & 0.53 & 0.68 & 0.18 & 0.03 & 0.60 & 0.14 & 0.01 \\
\hline Treatment $\times$ time & 0.59 & 0.19 & $<0.01$ & 0.14 & $<0.01$ & $<0.01$ & $<0.01$ & $<0.01$ \\
\hline Nutritional stress $\times$ time & 0.02 & $<0.01$ & 0.35 & 0.03 & $<0.01$ & $<0.01$ & 0.02 & $<0.01$ \\
\hline Treatment $\times$ nutritional stress $\times$ time & 0.56 & 0.14 & 0.67 & 0.75 & $<0.01$ & $<0.01$ & $<0.01$ & $<0.01$ \\
\hline
\end{tabular}

${ }^{\mathrm{z}}$ Significant tests $(P<0.05)$ are indicated in bold.

a biological inoculant composed of $2 \times 10^{8} \mathrm{cfu} / \mathrm{mL} A$. vinelandii. The biostimulant B2 is also a biological inoculant composed of $20 \times 10^{6} \mathrm{cfu} /$ $\mathrm{mL}$ Bacillus licheniformis, $20 \times 10^{6}$ cfu/mL Bacillus megaterium, $20 \times$ $10^{6} \mathrm{cfu} / \mathrm{mL} A$. vinelandii, and $20 \times 10^{6} \mathrm{cfu} / \mathrm{mL}$ Pseudomonas fluorescens. Finally, $\mathrm{B} 3$ is a root enhancer composed of $8.0 \%$ free amino acids (5.57\% glutamic acid, $1.20 \%$ alanine, $0.71 \%$ aspartic acid, $0.11 \%$ valine, and $0.41 \%$ thirteen amino acids); $6 \%$ total $\mathrm{N}$ derived from $3 \%$ organic [amino acids from vegetal origin, corn (Zea mays)], and $3 \%$ ammoniacal $\mathrm{N}\left(\mathrm{NH}_{4}-\mathrm{N}\right)$; micronutrients $[0.4 \%$ iron $(\mathrm{Fe})$, and $0.4 \%$ zinc $(\mathrm{Zn})]$; and $2.5 \%$ poly-saccharides.

Nutritional STRESS. A conventional fertilization program was compared with a nutritional stress program that was induced in half of the pots by performing (during the 24 weeks of experiment evaluation) two fertilization events instead of three, and by using half of the fertilizer dose $\left(17.5 \mathrm{~g} \cdot \mathrm{m}^{-2}\right)$ instead of $35 \mathrm{~g} \cdot \mathrm{m}^{-2}$ of a $16 \mathrm{~N}-3.5 \mathrm{P}-13.3 \mathrm{~K}-$ $3 \mathrm{Mg}-0.5 \mathrm{Fe}$ mineral compound fertilizer (Floranid TWIN Turf; Compo Expert, Münster, Germany). Nitrogen sources of the compound were $10.36 \%$ urea (isobutylidene diurea), $3.8 \% \mathrm{NH}_{4}-\mathrm{N}$, and $1.9 \%$ nitric. The conventional fertilization program (dose and application intervals) was set according to the fertilizer manufacturer's recommendations.

Turfgrass management. The experiments were carried out in a greenhouse with a temperature range set between 17 and $28^{\circ} \mathrm{C}$. Perennial ryegrass was sown 4 months before the starting date of the experiments at $20 \mathrm{~g} \cdot \mathrm{m}^{-2}$ in polyethylene pots $(40 \mathrm{~cm}$ high and $16 \mathrm{~cm}$ in diameter) filled with a sand $(0.6-\mathrm{mm}$ particle size $)$ and peat $(90 / 10 \mathrm{w} / \mathrm{w})$
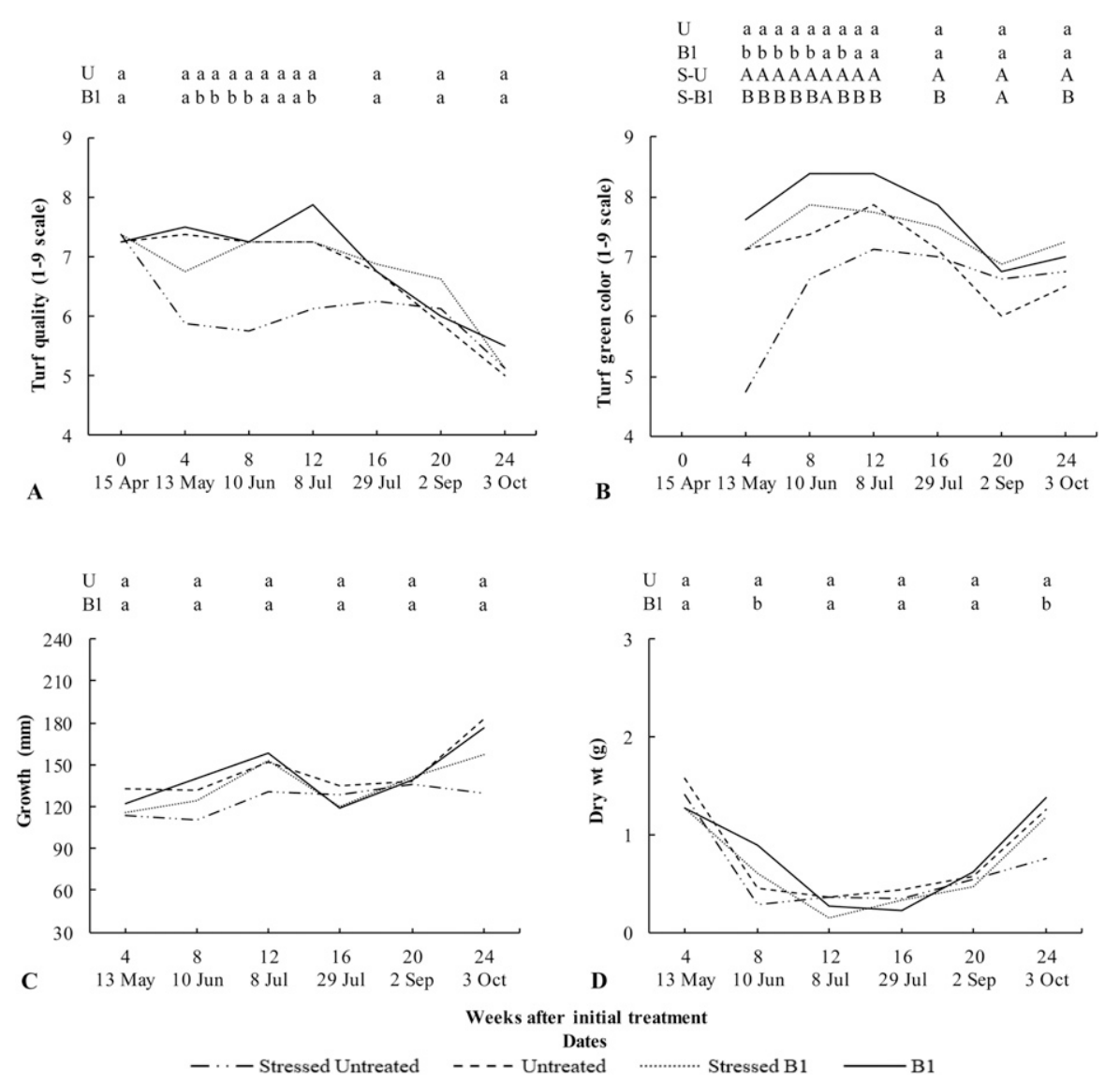

Fig. 1. Visual quality and growth of perennial ryegrass treated twice in a 2-week interval with the biostimulant 1 [BI (Azobio; Biotecnología del Mediterráneo)] at $5.4 \mathrm{~mL}(0.18 \mathrm{fl} \mathrm{oz})$ per pot in 2013 . The same letters above each evaluation date indicate nonsignificant differences according to Fisher's protected least significant difference test $(P<0.05)$ to identify significant differences among means for treatment effect. Stressed untreated (S-U): low fertilization program without BI treatment. Untreated (U): conventional fertilization program without Bl treatment. Stressed Bl (S-BI): low fertilization program with Bl biostimulant treatment. Bl: conventional fertilization program with $\mathrm{Bl}$ biostimulant treatment. Graphic B includes the analysis fixing fertilization factor (uppercase letters for nutritional stress and lowercase letters for conventional fertilization); turf quality ( 1 = dead turf, 9 = maximum quality); turf color $(1=$ light-green turf, 9 = dark-green turf); $1 \mathrm{~mm}=0.0394 \mathrm{inch} ; 1 \mathrm{~g}=0.0353 \mathrm{oz}$.

mixture. Turf management before biostimulant applications consisted of a starting fertilization with the compound at $35 \mathrm{~g} \cdot \mathrm{m}^{-2}$ before sowing, weekly mowing at $2 \mathrm{~cm}$, and irrigation on demand (avoiding leaching of water and nutrients) every 2 to $3 \mathrm{~d}$. On 15 Apr. 2013, B1, B2, and B3 


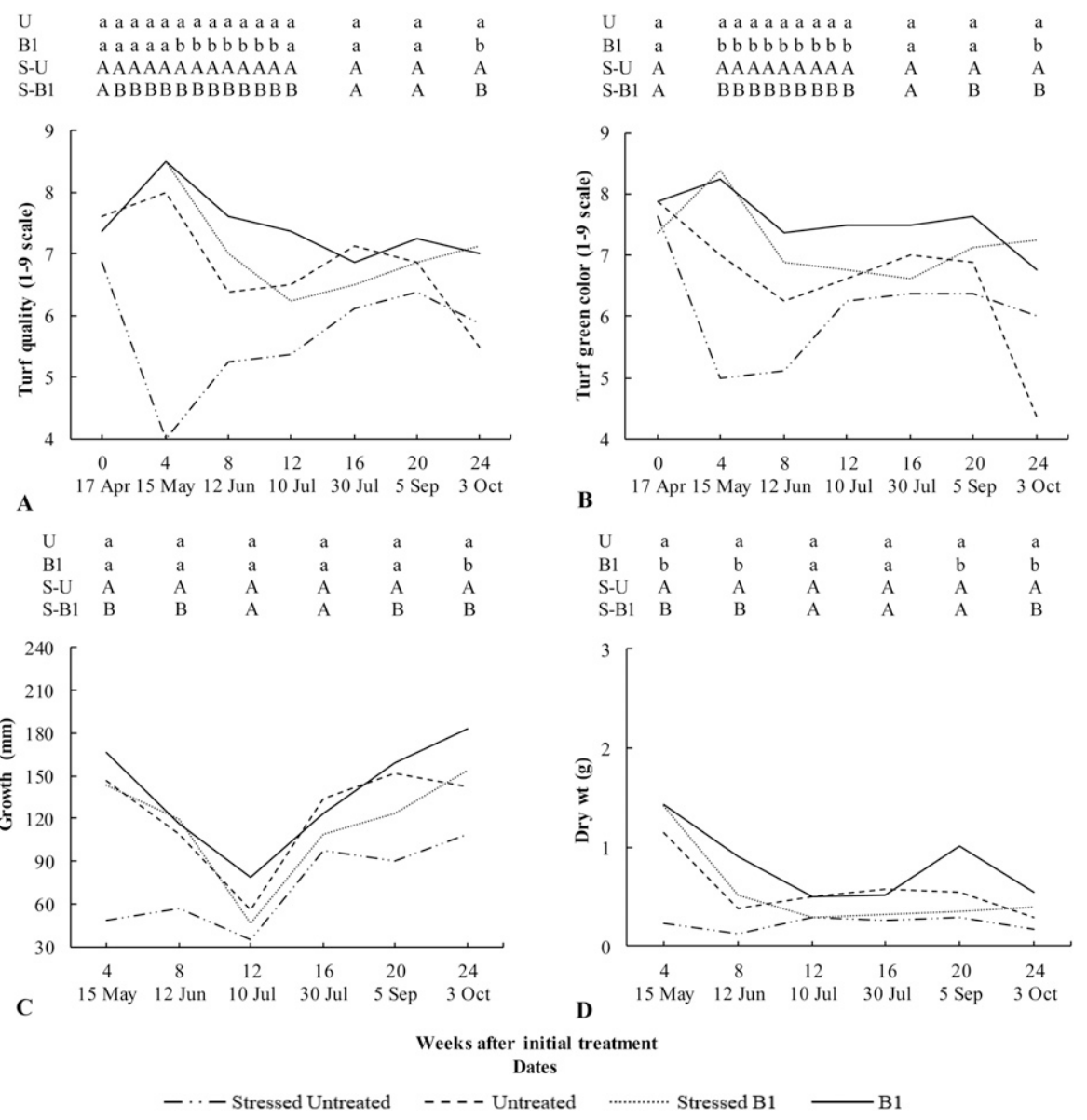

Fig. 2. Visual quality and growth of perennial ryegrass treated twice in a 2-week interval with the biostimulant 1 [BI (Azobio; Biotecnología del Mediterráneo)] at $5.4 \mathrm{~mL}(0.18 \mathrm{fl} \mathrm{oz})$ per pot in 2014 . The same letters above each evaluation date indicate nonsignificant differences according to Fisher's protected least significant difference test $(P<0.05)$ to identify significant differences among means for treatment effect. Stressed untreated (S-U): low fertilization program without Bl treatment. Untreated (U): conventional fertilization program without Bl treatment. Stressed BI (S-BI): low fertilization program with Bl biostimulant treatment. Bl: conventional fertilization program with $\mathrm{Bl}$ biostimulant treatment. Graphics A, B, C, and D include the analysis fixing fertilization factor (uppercase letters for nutritional stress and lowercase letters for conventional fertilization); turf quality ( 1 = dead turf, 9 = maximum quality); turf color $(1$ = light-green turf, $9=$ dark-green turf $) ; 1 \mathrm{~mm}=0.0394$ inch; $1 \mathrm{~g}=0.0353 \mathrm{oz}$.

Table 2. Repeated measures analysis of variance of perennial ryegrass treated twice in a 10-week interval with the biostimulant 1 [B1 (Azobio; Biotecnología del Mediterráneo)] at $5.4 \mathrm{~mL}(0.18 \mathrm{fl} \mathrm{oz})$ per pot in 2014 .

\begin{tabular}{lcccc}
\hline & \multicolumn{5}{c}{$\mathbf{2 0 1 4}$} \\
\cline { 2 - 5 } $\mathbf{B 1}$ & Turf quality & Turf color & Dry wt & Growth \\
\hline Treatment & $<\mathbf{0 . 0 1} \mathbf{1}^{\mathrm{z}}$ & $<\mathbf{0 . 0 1}$ & $<\mathbf{0 . 0 1}$ & $<\mathbf{0 . 0 1}$ \\
Nutritional stress & $<\mathbf{0 . 0 1}$ & $<\mathbf{0 . 0 1}$ & $<\mathbf{0 . 0 1}$ & $<\mathbf{0 . 0 1}$ \\
Time & $<\mathbf{0 . 0 1}$ & $<\mathbf{0 . 0 1}$ & $<\mathbf{0 . 0 1}$ & $<\mathbf{0 . 0 1}$ \\
Treatment $\times$ nutritional stress & 0.20 & 0.64 & 0.37 & $<\mathbf{0 . 0 1}$ \\
Treatment $\times$ time & $<\mathbf{0 . 0 1}$ & $<\mathbf{0 . 0 1}$ & $<\mathbf{0 . 0 1}$ & $<\mathbf{0 . 0 1}$ \\
Nutritional stress $\times$ time & $<\mathbf{0 . 0 1}$ & $<\mathbf{0 . 0 1}$ & $<\mathbf{0 . 0 1}$ & $<\mathbf{0 . 0 1}$ \\
Treatment $\times$ nutritional stress $\times$ time & $<\mathbf{0 . 0 1}$ & $\mathbf{0 . 0 1}$ & $<\mathbf{0 . 0 1}$ & $<\mathbf{0 . 0 1}$ \\
\hline
\end{tabular}

${ }^{\mathrm{z}}$ Significant tests $(P<0.05)$ are indicated in bold.

biostimulants were applied at 5.4 , 9.0 , and $2.3 \mathrm{~mL} /$ pot respectively, diluted in $450 \mathrm{~mL}$ of irrigation water (drench application), plus another $50 \mathrm{~mL}$ of water to ensure root absorption by washing off possible biostimulant residues on the leaves. The biostimulants $\mathrm{Bl}$ and $\mathrm{B} 3$ were applied twice in a 2 -week interval, and the $\mathrm{B} 2$ biostimulant was applied three times in a 2 -week interval. Application rates and intervals were decided according to information on high-input vegetable production from the manufacturer.

Nonstressed turf was fertilized three times during the following 6 months: on the biostimulant application date; 10 and 20 weeks after initial treatment (WAIT) with the compound at $35 \mathrm{~g} \cdot \mathrm{m}^{-2}$. Stressed turf was fertilized twice: on the biostimulant application date; and 10 WAIT with the same compound at 17.5 $\mathrm{g} \cdot \mathrm{m}^{-2}$. Total applied macronutrients in one application on the conventional fertilization program were $16.8 \mathrm{~g} \cdot \mathrm{m}^{-2}$ $\mathrm{N}, 3.6 \mathrm{~g} \cdot \mathrm{m}^{-2}$ phosphorus $(\mathrm{P})$, and $13.9 \mathrm{~g} \cdot \mathrm{m}^{-2}$ potassium $(\mathrm{K})$; and for the nutritional stress program, 5.6 $\mathrm{g} \cdot \mathrm{m}^{-2} \mathrm{~N}, 1.2 \mathrm{~g} \cdot \mathrm{m}^{-2} \mathrm{P}$, and $4.6 \mathrm{~g} \cdot \mathrm{m}^{-2}$ $\mathrm{K}$. Additionally, the biostimulant B3 supplied $3.4 \mathrm{~g} \cdot \mathrm{m}^{-2} \mathrm{~N}$ at both application events. Irrigation during the study was on soil/plant demand after measuring soil moisture content with a WET sensor (HH2 Moisture Meter; Delta-T Devices, Burwell, UK).

The irrigation dose range was 300 to $450 \mathrm{~mL} /$ pot every 2 to $7 \mathrm{~d}$. Mowing was carried out at a 4 -week interval at a $13 \mathrm{~mm}$ height. On 17 Apr. 2014, the B1, B2, and B3 experiments were exactly replicated, as in 2013, with two additional studies performed at the same time and only modifying the weekly interval application of $\mathrm{Bl}$ (10 instead of 2 , to extend the effect of $\mathrm{Bl}$ treatment observed in 2013) and B2 application rate $(0.6$ instead of $9 \mathrm{~mL} / \mathrm{pot}$, to avoid the phytotoxicity effect observed in 2013). The choice of the $0.6 \mathrm{~mL} /$ pot rate for the additional B2 study (B2-0.6) was made after a dose response screening experiment (data not shown) applying 10 rates in the range 0 to $20 \mathrm{~mL} / \mathrm{pot}$, and the rate was chosen for the best enhancement of turf quality with low phytotoxicity.

Turfgrass assessments. Two turfgrass characteristics were evaluated weekly. Visual turf quality was determined using a 1 to 9 scale where 1 is dead turf, 6 is acceptable quality, and 9 is maximum quality (Christians et al., 1979); and visual turf color was determined using a 1 to 9 scale where 1 is a light-green turf, and 9 is 
a dark-green turf (Morris and Shearman, 1998). In 2013, color was initially evaluated after 5 WAIT when treated turf started to differ from untreated turf; while in 2014, it was evaluated after 0 WAIT.

Turfgrass growth in a 4-week interval period was evaluated six times
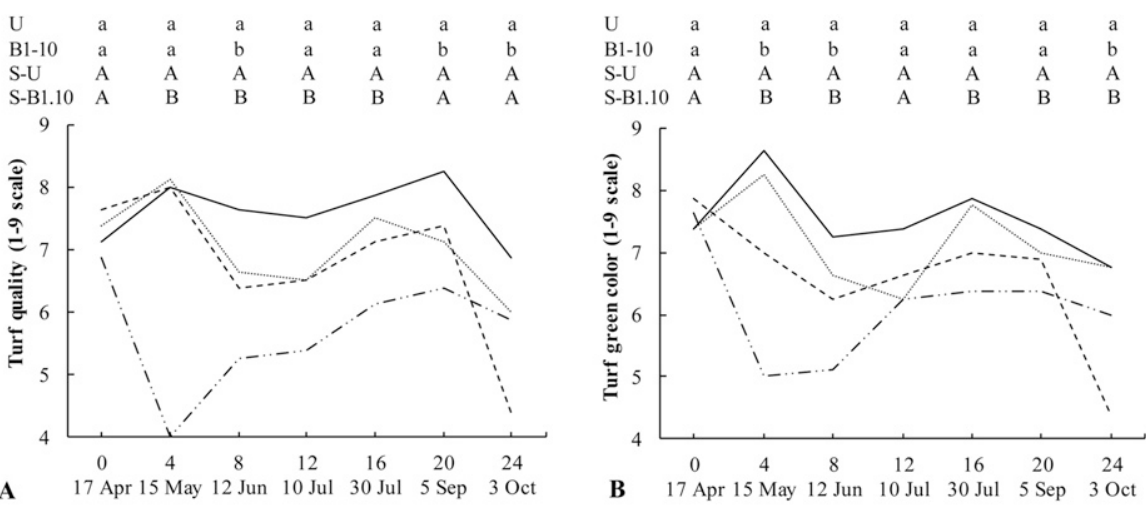

B 17 Apr 15 May 12 Jun 10 Jul 30 Jul 5 Sep 3 Oct
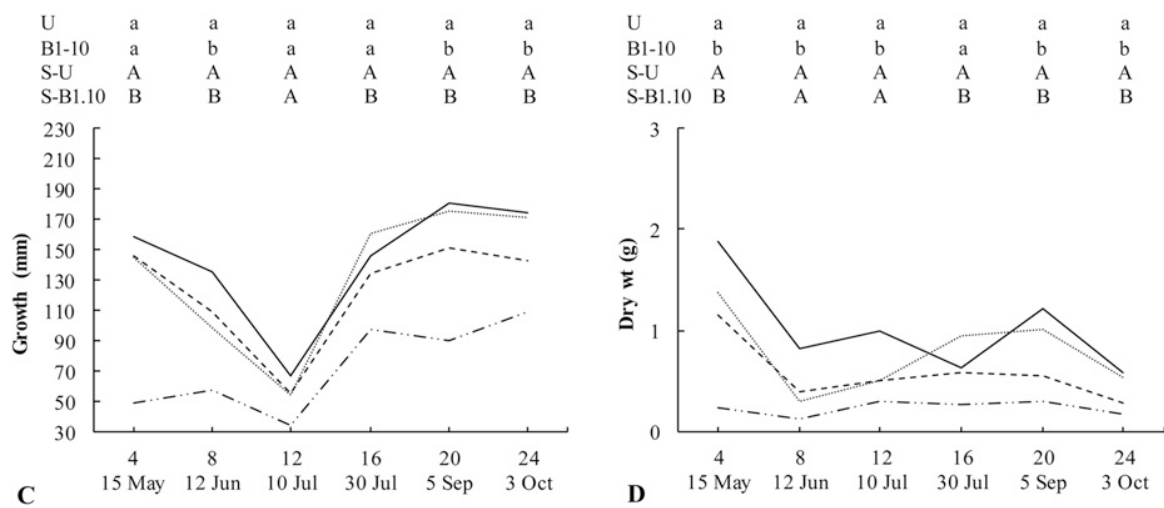

$$
\begin{gathered}
\text { Weeks after initial treatment } \\
\text { Dates } \\
-\cdots-\cdots \text { Stressed Untreated } \\
-\cdots-- \text { Untreated }- \text { Stressed B1-10 - B1-10 }
\end{gathered}
$$

Fig. 3. Visual quality and growth of perennial ryegrass treated twice in a 10 -week interval with the biostimulant 1 [BI (Azobio; Biotecnología del Mediterráneo)] at $5.4 \mathrm{~mL}(0.18 \mathrm{fl} \mathrm{oz})$ per pot in 2014 . The same letters above each evaluation date indicate nonsignificant differences according to Fisher's protected least significant difference test $(P<0.05)$ to identify significant differences among means for treatment effect. Stressed untreated $(S-U)$ : low fertilization program without BI treatment. Untreated (U): conventional fertilization program without B1 treatment. Stressed B1-10 (S-B1.10): low fertilization program with B1 biostimulant treatment. B1-10: conventional fertilization program with $\mathrm{Bl}$ biostimulant treatment. Graphics A, B, C, and D include the analysis fixing fertilization factor (uppercase letters for nutritional stress and lowercase letters for conventional fertilization); turf quality ( 1 = dead turf, 9 = maximum quality); turf color $(1=$ light-green turf, $9=$ dark-green turf $) ; 1 \mathrm{~mm}=0.0394 \mathrm{inch} ; 1 \mathrm{~g}=0.0353 \mathrm{oz}$.

during the experiment. Five measurements per pot were taken using a 1 -mm-accurate ruler and then turf clippings were removed, oven dried for $24 \mathrm{~h}$ at $75^{\circ} \mathrm{C}$, and weighed using a $0.0 \mathrm{l}$-g-accuracy weighing scale.

STATISTICAL ANALYSIS. Data from 2013 and 2014 were analyzed separately. The data set obtained in a 4-week interval period was subjected to a three-way repeated measures analysis of variance (ANOVA) to evaluate the effects of treatment, nutritional stress, and time on turf quality, color, growth, and clippings' dry weight. When a significant three-way interaction occurred, a two-way repeated measures ANOVA was performed using nutritional stress as a fixed factor to evaluate the twoway interaction of treatment $x$ time at each level of nutritional stress (conventional or stressed). Multiple pairwise comparisons were executed to determine the effect of treatment at every level of time. Fisher's protected least significant difference (LSD) test was used at the $0.05 P$ level to identify significant differences during the experiments and between means for treatment main effect and its interaction with time. Additionally, a weekly data set of turf quality and color was used to perform the three-way repeated measures ANOVA to evaluate the initial response of perennial ryegrass to the $\mathrm{Bl}$ biostimulant. The statistical analysis was carried out with statistical software (Statgraphics Centurion version 18.1.12; StatPoint Technologies, Warrenton, VA).

\section{Results and discussion}

RESPONSE OF PERENNIAL RYEGRASS TO BIOSTIMULANT $\mathbf{l}$ (Bl). The ANOVA revealed nonsignificant three-way

\begin{tabular}{|c|c|c|c|c|c|c|c|c|}
\hline Treatment & 0.13 & $<0.01$ & $<0.01$ & $<0.01$ & $<0.01$ & $<0.01$ & $<0.01$ & $<0.01$ \\
\hline Time & $<0.01$ & $<0.01$ & $<0.01$ & $<0.01$ & $<0.01$ & $<0.01$ & $<0.01$ & $<0.01$ \\
\hline Treatment $\times$ nutritional stress & 0.13 & 0.16 & 0.77 & 0.31 & $<0.01$ & 0.01 & 0.07 & $<0.01$ \\
\hline Treatment $\times$ time & $<0.01$ & 0.02 & 0.01 & $<0.01$ & $<0.01$ & $<0.01$ & $<0.01$ & $<0.01$ \\
\hline Treatment $\times$ nutritional stress $\times$ time & 0.09 & $<0.01$ & 0.57 & 0.28 & $<0.01$ & $<0.01$ & $<0.01$ & 0.01 \\
\hline
\end{tabular}
interactions among factors in 2013

Table 3. Repeated measures analysis of variance of perennial ryegrass treated three times in a 2 -week interval with the biostimulant 2 [B2 (Rizobacter; Biotecnología del Mediterráneo)] at $9 \mathrm{~mL}(0.3 \mathrm{fl} \mathrm{oz})$ per pot in 2013 and 2014.

${ }^{\mathrm{z}^{2}}$ Significant tests $(P<0.05)$ are indicated in bold. 

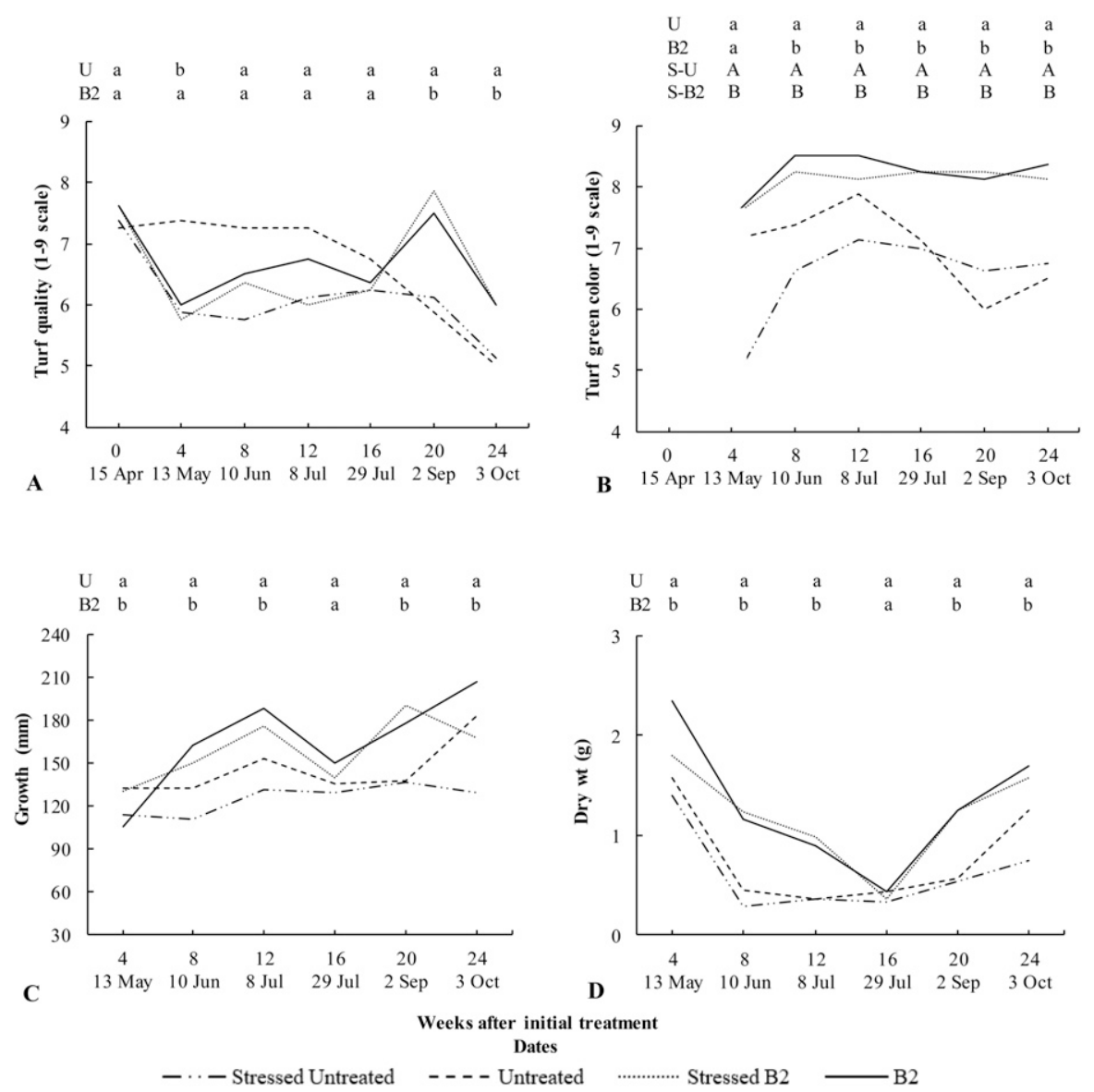

Fig. 4. Visual quality and growth of perennial ryegrass treated three times in a 2-week interval with the biostimulant 2 [B2 (Rizobacter; Biotecnología del Mediterráneo)] at $9 \mathrm{~mL}(0.3 \mathrm{fl} \mathrm{oz})$ per pot in 2013 . The same letters above each evaluation date indicate nonsignificant differences according to Fisher's protected least significant difference test $(P<0.05)$ to identify significant differences among means for treatment effect. Stressed untreated (S-U): low fertilization program without B2 treatment. Untreated (U): conventional fertilization program without B2 treatment. Stressed B2 (S-B2): low fertilization program with B2 biostimulant treatment. B2: conventional fertilization program with B2 biostimulant treatment. Graphic B includes the analysis fixing fertilization factor (uppercase letters for nutritional stress and lowercase letters for conventional fertilization). Turf quality: 1 = dead turf and 9 = maximum quality; turf color: 1 = light-green turf and $9=$ dark-green turf; $1 \mathrm{~mm}=0.0394$ inch; $1 \mathrm{~g}=0.0353 \mathrm{oz}$.

(Table 1). The two-way interaction between treatment and time for dry weight was significant $(P<0.01)$ and more clippings' dry weight was obtained only on two of the six sampling dates (8 and 24 WAIT) from the Bl-treated turf rather than the untreated turf (Fig. 1D). The treatment effect was also significant for turf quality $(P=0.04)$ and turf color $(P<0.01)$; treated turf had better quality and color than untreated. This main factor effect seemed to occur in the first half of the experimental period (Fig. IA and B). As there was interest in finding out the extension of the observed effects after treatments, a repeated measures ANOVA was performed using the available weekly data for turf quality and color between 4 and 12 WAIT. An interaction between treatment and fertilization $(P<0.05)$ was obtained for turf quality, and a more marked turf quality increase was observed when turf was nutritionally stressed than for conventional fertilization. This finding is relevant because it suggests $A$. vinelandii replaces the nutritional role of classic mineral fertilizers, at least temporarily; and, therefore, less mineral fertilization would be required. In addition, the expected significant effects of the $\mathrm{Bl}$ treatment were detected between 5 and 8 WAIT and at 12 WAIT (Fig. 1A). A three- way interaction was obtained for turf color $(P<0.01)$ when using weekly data. Figure IB illustrates the effect of the $\mathrm{Bl}$ treatment on turf color during the 4 to 12 WAIT period for each fertilization level; the green color increase was significant regardless of the nutritional status. Turf growth in 2013 was unaffected by the $\mathrm{Bl}$ treatment (Fig. lC).

In 2014 , the repeated measures ANOVA (Table 1) revealed threeway interactions for all the determined turf characteristics. Therefore, fertilization was considered a fix factor, and a new repeated measures ANOVA was conducted for the 2 to 11 WAIT period for turf quality and color, and also for the whole period for turf growth and dry clippings' weight, with the following four findings (Fig. 2). 1) With conventional fertilization, the $\mathrm{Bl}$ treatment improved turf quality on seven evaluation dates, from 5 to 11 WAIT, while it improved turf quality throughout the analyzed period ( 2 to 11 WAIT) under nutritional stress (Fig. 2A). 2) The $\mathrm{Bl}$ treatment improved turf color throughout the period ( 2 to 11 WAIT) from 5.6 to 7.3 with low fertilization, and from 6.7 to 7.8 with conventional fertilization (Fig. 2B). 3) Turf growth (Fig. 2C) only improved on one date after applying $\mathrm{Bl}$ with conventional fertilization, but improved with low fertilization on four of six dates. 4) The clippings' dry weight yield (Fig. 2D) under nutritional stress increased because of $\mathrm{Bl}$ treatment from 0.23 to 0.55 $\mathrm{g}$, and from 0.58 to $0.82 \mathrm{~g}$ with conventional fertilization.

Briefly for both years, the Bl treatment effect on perennial ryegrass was first observed at around 4 to 5 WAIT and lasted noncontinuously for 2 to 3 months. When data were averaged over both years, the following improvements were noted: turf quality from 6.0 to 6.9 ; turf color from 6.4 to 7.6 ; and turf growth and clippings' dry weight increased by $21.2 \%$ and $33.9 \%$, respectively.

When changing the Bl application interval from 2 to 10 weeks (B110), significant three-way interactions were detected for all the evaluated characteristics (Table 2). Therefore, repeated measures ANOVA were conducted with fertilization as a fix factor. The results are shown in Fig. 3 . When Bl-10 was applied under 

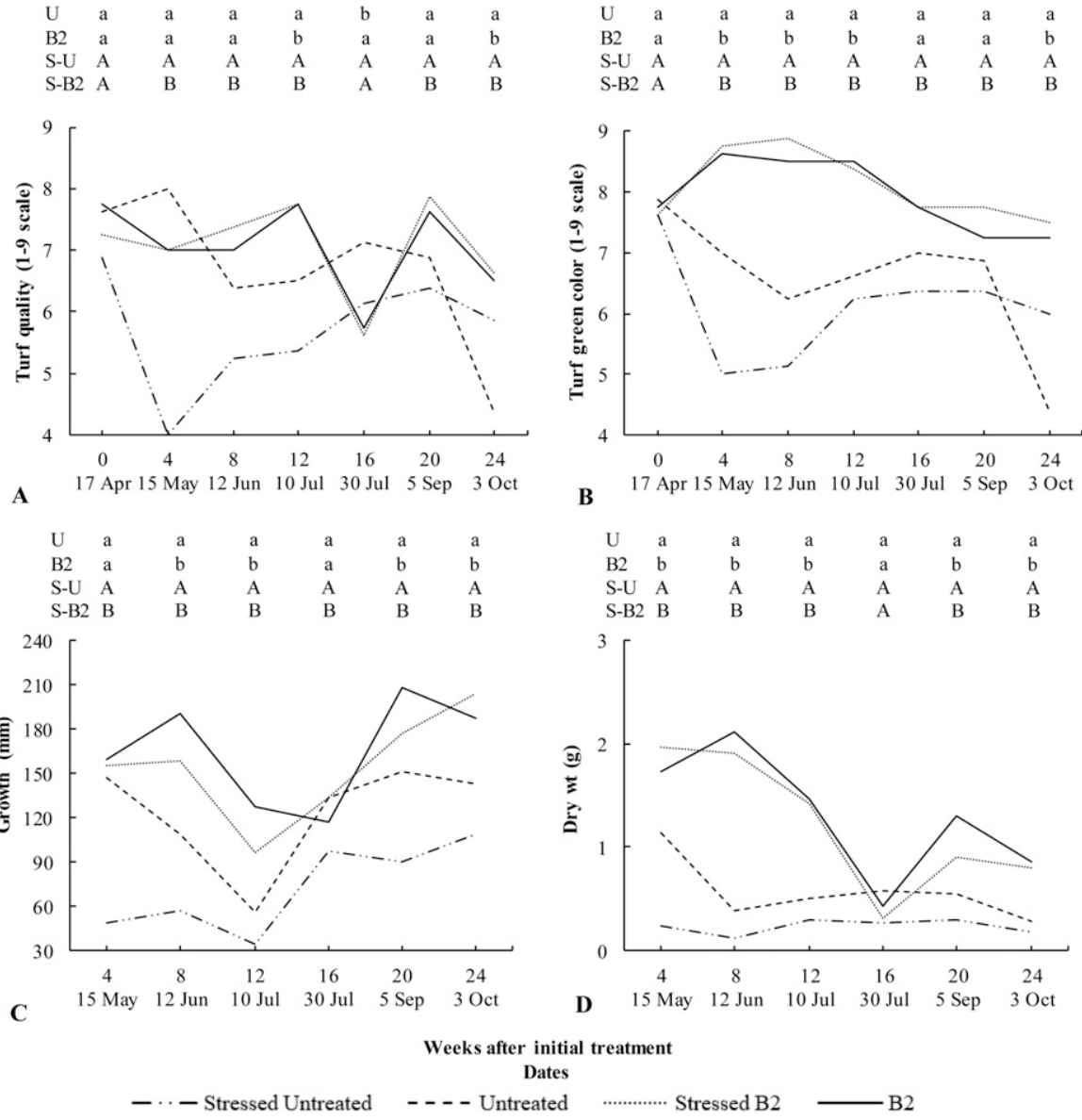

Fig. 5. Visual quality and growth of perennial ryegrass treated three times in a 2-week interval with the biostimulant 2 [B2 (Rizobacter; Biotecnología del Mediterráneo)] at $9 \mathrm{~mL}(0.3 \mathrm{fl} \mathrm{oz})$ per pot in 2014. The same letters above each evaluation date indicate nonsignificant differences according to Fisher's protected least significant difference test $(P<0.05)$ to identify significant differences among means for treatment effect. Stressed untreated (S-U): low fertilization program without B2 treatment. Untreated (U): conventional fertilization program without B2 treatment. Stressed B2 (S-B2): low fertilization program with B2 biostimulant treatment. B2: conventional fertilization program with B2 biostimulant treatment. Graphics A, B, C, and D include the analysis fixing fertilization factor (uppercase letters for nutritional stress and lowercase letters for conventional fertilization); turf quality ( 1 = dead turf, 9 = maximum quality); turf color $(1$ = light-green turf, $9=$ dark-green turf $) ; 1 \mathrm{~mm}=0.0394 \mathrm{inch} ; 1 \mathrm{~g}=0.0353 \mathrm{oz}$.

Table 4. Repeated measures analysis of variance of perennial ryegrass treated three times in a 2-week interval with the biostimulant 2 [B2 (Rizobacter; Biotecnología del Mediterráneo $)]$ at $0.6 \mathrm{~mL}(0.02 \mathrm{fl} \mathrm{oz})$ per pot in 2014.

\begin{tabular}{lcrrr}
\hline & \multicolumn{4}{c}{$\mathbf{2 0 1 4}$} \\
\cline { 2 - 5 } B2 & Turf quality & Turf color & Dry wt & Growth \\
\hline Treatment & $<\mathbf{0 . 0 1} \mathbf{1}^{\mathrm{z}}$ & $<\mathbf{0 . 0 1}$ & $<\mathbf{0 . 0 1}$ & $<\mathbf{0 . 0 1}$ \\
Nutritional stress & $<\mathbf{0 . 0 1}$ & $\mathbf{0 . 0 1}$ & $<\mathbf{0 . 0 1}$ & $<\mathbf{0 . 0 1}$ \\
Time & $<\mathbf{0 . 0 1}$ & $<\mathbf{0 . 0 1}$ & $<\mathbf{0 . 0 1}$ & $<\mathbf{0 . 0 1}$ \\
Treatment $\times$ nutritional stress & 0.15 & 0.43 & $\mathbf{0 . 0 4}$ & $<\mathbf{0 . 0 1}$ \\
Treatment $\times$ time & $\mathbf{0 . 0 1}$ & $<\mathbf{0 . 0 1}$ & $<\mathbf{0 . 0 1}$ & $\mathbf{0 . 0 1}$ \\
Nutritional stress $\times$ time & $<\mathbf{0 . 0 1}$ & $<\mathbf{0 . 0 1}$ & $<\mathbf{0 . 0 1}$ & $<\mathbf{0 . 0 1}$ \\
Treatment $\times$ nutritional stress $\times$ time & $<\mathbf{0 . 0 1}$ & 0.15 & 0.10 & 0.07 \\
\hline
\end{tabular}

${ }^{\mathrm{z}}$ Significant tests $(P<0.05)$ are indicated in bold.

conventional fertilization, an increase in turf quality of 1.4 and 2.5 took place at 20 and 24 WAIT, respectively.
In contrast, the observed turfgrass improvement between 4 to 16 WAIT under nutritional stress was not detected at the end of the experimental period (Fig. 3A). Turf color improvement was detected in more occasions under nutritional stress than with conventional fertilization (Fig. 3B), and once again with excellent results at 24 WAIT (14 weeks after the second Bl-10 application). Growth and clippings' dry weight of Bl-10-treated turf had also improved by the end of the experimental period, at 20 and 24 WAIT with conventional fertilization, and at 16,20 , and 24 WAIT under nutritional stress (Fig. 3C and D), which may be considered an indicator of plant health. Figure 3 shows many significant differences for the treatment factor but not on a continuous basis. This can be because of the less active period for perennial ryegrass in the warmest weeks [July (12 to 16 WAIT)] compared with the beginning and final weeks of the experiment, or because the 8-week interval application difference between the main $\mathrm{Bl}$ experiment and the minor study was too long, an indication that biostimulant management is crucial.

These results suggest the importance of establishing a biostimulant program to obtain the best turfgrass performance, because the $\mathrm{Bl}$ effect was prolonged from 12 to 24 weeks by simply changing the interval application period from 2 to 10 weeks. At the end of the study (24 WAIT), both turf quality and color fell within the 6.0 to 6.9 range for the B1-10treatment, and within the 4.4 to 6.0 range for untreated turf. Moreover, a $29.6 \%$ growth increase and a $58.9 \%$ clipping recovery increase were recorded for the Bl-treated turf compared with the untreated turf. An effect of $A$. vinelandii inoculation was also observed by Delić et al. (2013) when reporting beneficial effects on the yield of another Lolium species [italian ryegrass (L. multiflorum)] as $\mathrm{N}$ assimilation increased. In general, the effect of $\mathrm{Bl}$ on perennial ryegrass quality lasted until 12 WAIT. Another application at that point, instead of the performed 2 -week interval application, prolonged this beneficial effect, as the minor Bl experiment in 2014 demonstrated.

RESPONSE OF PERENNIAL RYEGRASS to Biostimulant 2 (B2). Table 3 shows the repeated measures ANOVA for the B2 treatment on perennial ryegrass. A three-way interaction was 
detected in 2013 for turf color $(P<$ $0.01)$. Therefore, fertilization was considered a fix factor, and another repeated measures ANOVA was
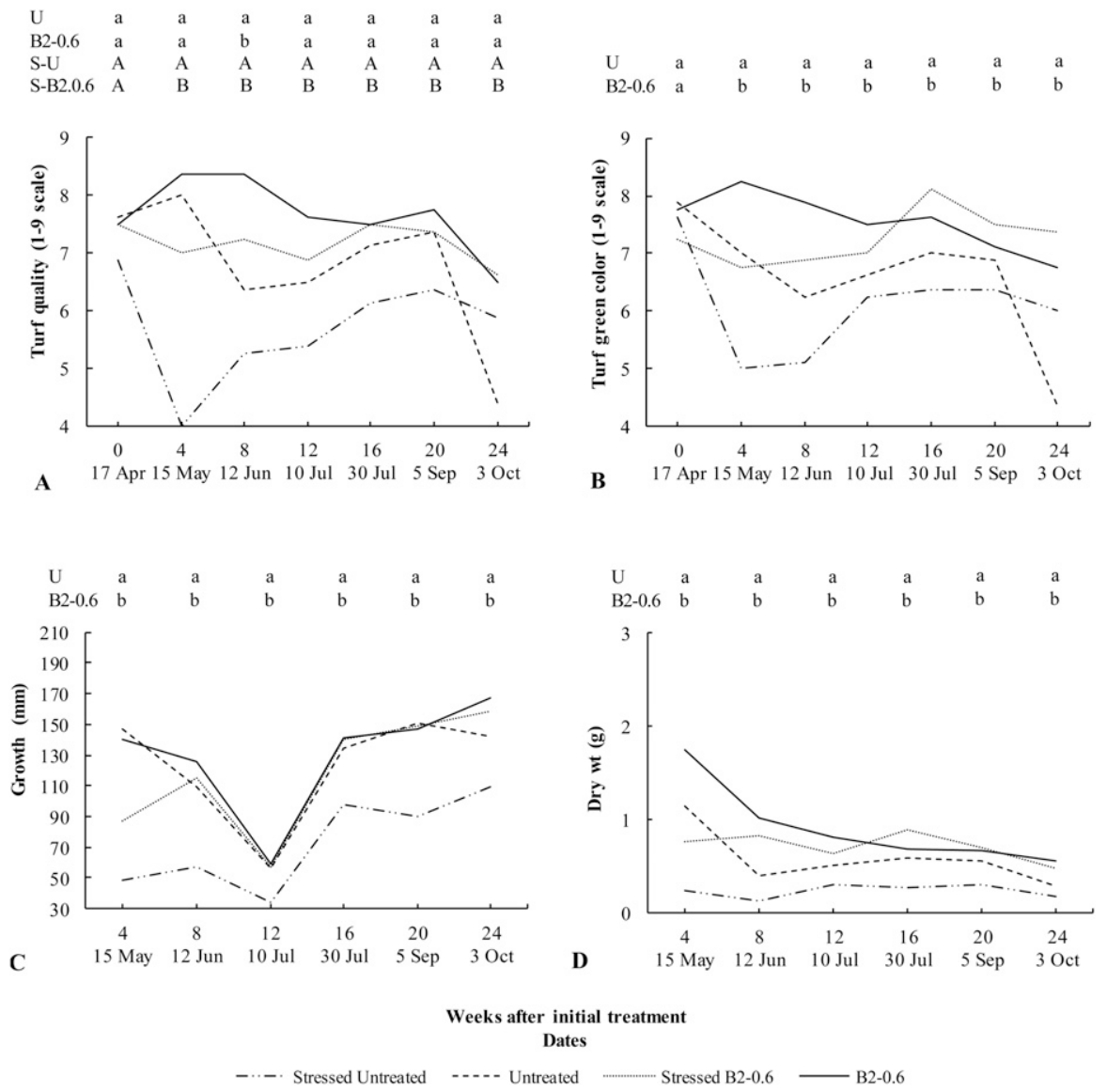

Fig. 6. Visual quality and growth of perennial ryegrass treated three times in a 2-week interval with the biostimulant 2 [B2 (Rizobacter; Biotecnología del Mediterráneo $)$ ] at $0.6 \mathrm{~mL}(0.02 \mathrm{fl} \mathrm{oz})$ per pot in 2014 . The same letters above each evaluation date indicate nonsignificant differences according to Fisher's protected least significant difference test $(P<0.05)$ to identify significant differences among means for treatment effect. Stressed untreated (S-U): low fertilization program without B2 treatment. Untreated (U): conventional fertilization program without B2 treatment. Stressed B2 (S-B2.0.6): low fertilization program with B2 biostimulant treatment. B2-0.6: conventional fertilization program with B2 biostimulant treatment. Graphic A includes the analysis fixing fertilization factor (uppercase letters for nutritional stress and lowercase letters for conventional fertilization); turf quality ( $1=$ dead turf, $9=$ maximum quality); turf color $(1=$ light-green turf, 9 = dark-green turf); $1 \mathrm{~mm}=0.0394 \mathrm{inch} ; 1 \mathrm{~g}=0.0353 \mathrm{oz}$. conventional fertilization, and from 6.5 to 8.1 under nutritional stress. Table 3 also shows significant effects in 2013 for the treatment factor on turf growth $(P<0.01)$ and clippings' dry weight $(P<0.01)$, and the treatment $\times$ time interactions were also significant. Figure 4C and D show that both measured characteristics improved for almost the whole experiment, with $63.0 \%$ growth and a $78.6 \%$ clipping yield. The treatment factor had no significant effect on turf quality in 2013 (Table 3). The turf quality response in 2013 was unlike the $\mathrm{Bl}$ treatment because a negative effect of B2 treatment started at 4 WAIT (Fig. 4A), being treated turf quality 5.9 , while the untreated turf quality was 6.6. This negative effect was caused by phytotoxicity localized at the tip of the leaf that appeared at 1 WAIT and lasted until 16 WAIT. Throughout this period, phytotoxicity gradually declined despite reappearing after every mowing. At the end of the experimental period (20 and 24 WAIT), this negative effect was reversed, and the B2-treated turf quality improved, being the untreated turf quality at 24 WAIT 5.1 and 6.0 for the treated turf.

Phytotoxicity reappeared in 2014 , which negatively affected turf quality. Table 3 reveals the three-way interactions for all the measured characteristics. Therefore, the statistical analysis was rerun by fixing the fertilization factor. The results are presented in Fig. 5. In 2014, the beneficial effect of B2 on turf quality under nutritional stress was observed for almost the whole experiment (Fig. $5 \mathrm{~A}$ ). with a global average increase of 1.4 because of the $\mathrm{B} 2$ treatment. With conventional fertilization, the benefit of B2 was observed only at 12 and 24 WAIT with 1.3 and 2.1 turf quality improvement, respectively. Turf color

Table 5. Repeated measures analysis of variance of perennial ryegrass treated twice in a 2 -week interval with the biostimulant 3 [B3 (Rizosan Eco; Biotecnología del Mediterráneo)] at $2.3 \mathrm{~mL}(0.08 \mathrm{fl} \mathrm{oz})$ per pot in 2013 and 2014.

\begin{tabular}{|c|c|c|c|c|c|c|c|c|}
\hline \multirow[b]{2}{*}{ B3 } & \multicolumn{4}{|c|}{2013} & \multicolumn{4}{|c|}{2014} \\
\hline & Turf quality & Turf color & Dry wt & Growth & Turf quality & Turf color & Dry wt & Growth \\
\hline Treatment & $<0.01^{\mathrm{z}}$ & $<0.01$ & $<0.01$ & $<0.01$ & $<0.01$ & $<0.01$ & $<0.01$ & $<0.01$ \\
\hline Nutritional stress & 0.05 & 0.31 & 0.01 & $<0.01$ & $<0.01$ & 0.04 & $<0.01$ & $<0.01$ \\
\hline Time & $<0.01$ & $<0.01$ & $<0.01$ & $<0.01$ & $<0.01$ & $<0.01$ & $<0.01$ & $<0.01$ \\
\hline Treatment $\times$ nutritional stress & 0.07 & 0.02 & 0.77 & 0.86 & 0.02 & 0.02 & 0.14 & $<0.01$ \\
\hline Treatment $\times$ time & $<0.01$ & 0.05 & $<0.01$ & $<0.01$ & $<0.01$ & $<0.01$ & $<0.01$ & $<0.01$ \\
\hline
\end{tabular}

${ }^{{ }^{Z}}$ Significant tests $(P<0.05)$ are indicated in bold 

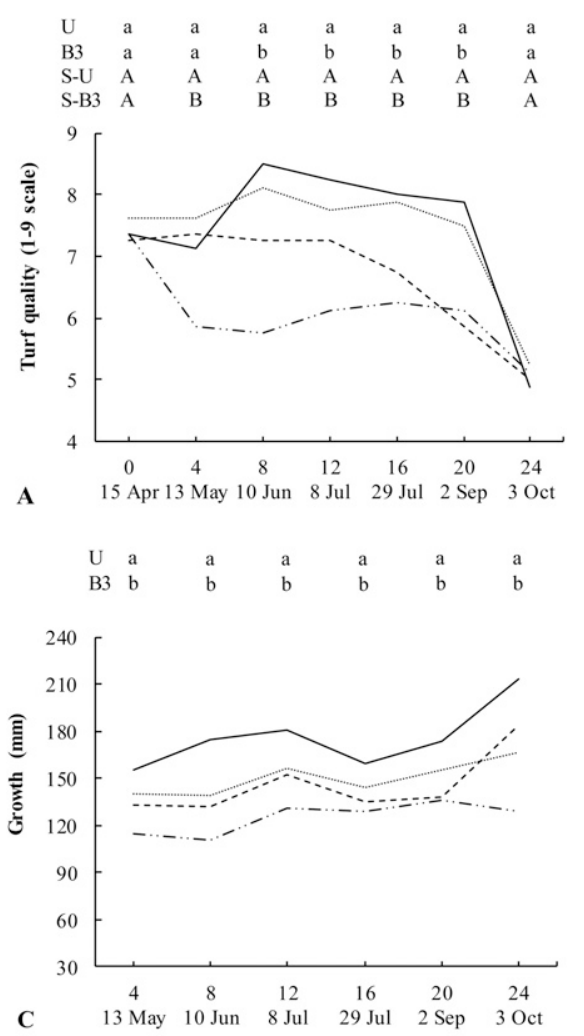
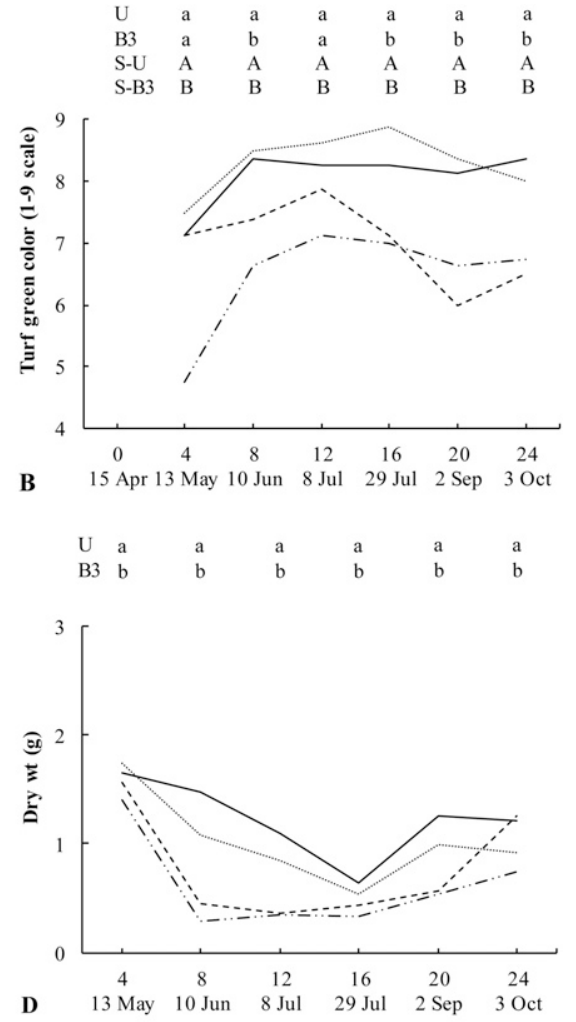

$$
\begin{aligned}
& \text { Weeks after initial treatment } \\
& \text { Dates } \\
& \text {-.... Stressed Untreated } \quad \text {-..... Untreated _ Stressed B3 — B3 }
\end{aligned}
$$

Fig. 7. Visual quality and growth of perennial ryegrass treated twice in a 2-week interval with the biostimulant 3 [B3 (Rizosan Eco; Biotecnología del Mediterráneo $)]$ at $2.3 \mathrm{~mL}(0.08 \mathrm{fl} \mathrm{oz})$ per pot in 2013 . The same letters above each evaluation date indicate nonsignificant differences according to Fisher's protected least significant difference test $(P<0.05)$ to identify significant differences among means for treatment effect. Stressed untreated (S-U): low fertilization program without $\mathrm{B} 3$ treatment. Untreated (U): conventional fertilization program without B3 treatment. Stressed B3 (S-B3): low fertilization program with B3 biostimulant treatment. B3: conventional fertilization program with B3 biostimulant treatment. Graphics A and B include the analysis fixing fertilization factor (uppercase letters for nutritional stress and lowercase letters for conventional fertilization); turf quality ( 1 = dead turf, 9 = maximum quality); turf color $(1=$ light-green turf, 9 = dark-green turf); $1 \mathrm{~mm}=0.0394 \mathrm{inch} ; \mathrm{g}=0.0353 \mathrm{oz}$.

improved with the $\mathrm{B} 2$ treatment for conventional fertilization at $4,8,12$, and 24 WAIT (Fig. 5B), with a global increment of 1.3 from 6.6 to 7.9 . Under nutritional stress, the B2 treatment was even greater because it was detected for almost the whole experiment, and turf color values reached 8.1. The turfgrass growth and clippings' dry weight response due to the B2 treatment in 2014 were similar (Fig. 5C and D). The global average clippings' dry weight increases were $430.4 \%$ and $125.9 \%$ for low and conventional fertilization, and with global average growth increases of $111.8 \%$ and $34.1 \%$ for low and conventional fertilization, both respectively.
Acikgoz et al. (2016) also observed a slight increase in color and a marked increase in clipping yield when treating perennial ryegrass and tall fescue with $B$. subtilis and $B$. megaterium combined with conventional $\mathrm{N}$ fertilizers (compared with mineral $\mathrm{N}$ fertilization alone). The aforementioned authors suggested that incorporating biostimulant into a fertilization program of the tested turfgrass species could reduce the applied $\mathrm{N}$ dose, especially during the post-stress recuperative period.

The results obtained with the $\mathrm{B} 2$ treatment were more consistent than the Bl treatment across both years. This can be explained by Bl containing only one microorganism, and by $\mathrm{B} 2$ being a mixture of four different microorganisms, including Bacillus and Pseudomonas, which are among the most important plant growth-promoting rhizobacteria (Podile and Kishore, 2007). The biostimulant B2 was better capable than $\mathrm{Bl}$ of improving microorganism-turfgrass relations under nutritional stress. This statement is supported by Zhang et al. (2013a), who reported that the presence of multiple and diverse microbes can lead to versatility and environmental tolerance because they might respond differently to a given environmental change, which would result in the equilibrium of $\mathrm{N}$-cycling processes.

The observed phytotoxicity could be related to application procedures, for example dose, application timing according to stress, foliar/root application, mowing procedure around application day, and so forth. A 9$\mathrm{mL} /$ pot rate is a very high application dose, and a lower dose could improve turf quality by not leading to the observed phytotoxicity. When applying $0.6 \mathrm{~mL}$ of $\mathrm{B} 2$ per pot instead of 9 $\mathrm{mL}$ (Table 4), a three-way interaction for turf quality was detected $(P<$ $0.01)$. In this case, the analysis was rerun by fixing the fertilization factor. The results are shown in Fig. 6A; under nutritional stress, the B2-0.6 treatment improved turf quality from 4 to 24 WAIT, with a global average increment of 1.5. With conventional fertilization, turf quality increased only on two dates: 2.0 at 8 WAIT and 2.1 at 24 WAIT. Table 4 shows how the treatment factor had a significant effect on turf color $(P<0.01)$, while Fig. 6B depicts the effect of B20.6 treatment over time. The B2-0.6 treatment improved turf color from 4 to 24 WAIT. The increment was 1.1, which was a global data average. In addition, a two-way interaction between treatment and fertilization factors was detected for growth $(P<$ $0.01)$ and clippings' dry weight $(P=$ 0.04 ). The results in Fig. $6 \mathrm{C}$ and $\mathrm{D}$ show that both measured turf characteristics improved with B2-0.6 treatment from 4 to 24 WAIT, and this increment was even bigger under nutritional stress. Growth increment with conventional fertilization was $5.8 \%$ and $59.6 \%$ for clipping yield, and it was $62.1 \%$ and $208.7 \%$ under nutritional stress, both respectively. 
The B2-0.6 study (Fig. 6) demonstrated a dose-response effect compared with the main $\mathrm{B} 2$ study $[9 \mathrm{~mL} /$ pot (Figs. 4 and 5)]. At 8 WAIT, during the mid-B2 best effect period, turf quality improved from 7.0 to 8.4 (Figs. 5A vs. 6A) because only a few phytotoxicity symptoms were observed at $0.6 \mathrm{~mL} /$ pot. Turf color declined from 8.5 to 7.9 (Figs. 5B vs. 6B). Less growth was measured with 190.3 vs. $125.3 \mathrm{~mm}$ (Figs. 5C vs. 6C); clippings' dry weight values were lower, with 2.1 vs. $0.8 \mathrm{~g}$ (Figs. $5 \mathrm{D}$ vs. $6 \mathrm{D})$.

Despite lowering the dose from 9 to $0.6 \mathrm{~mL} / \mathrm{pot}$, the response of the B2-treated turf was greater than on the untreated turf for all the assessments made for almost the whole experiment (Fig. 6). The origin of phytotoxicity could not be determined. It is believed that $A$. vinelandii could not produce phytotoxicity because the bacterium was applied at a lower concentration than in the safe Bl treatment. No reports on phytotoxicity were found with the other bacteria in the mixture (Bacillus sp. and P. fluorescens), the extensive report on plant growth-promoting rhizobacteria by Ruzzi and Aroca (2015), and in the biostimulant turfgrass review by Calvo et al. (2014). Perhaps the origin of phytotoxicity could be the large applied dose, together with three applications in 1 month, instead of two applications in 1 month, as in the Bl treatment.

RESPONSE OF PERENNIAL RYEGRASS TO BIOSTIMULANT 3 (B3). A repeated measures ANOVA was conducted to unveil the effect of B3 on perennial ryegrass (Table 5). Three-way interactions were detected for turf quality $(P>0.01)$ and color $(P<0.01)$ in 2013 . As a result, the fertilization factor was fixed, and the ANOVA was rerun. The results are shown in Fig. 7A and B. For conventional fertilization, turf quality increased between 8 and 20 WAIT, with a global average improvement of 0.7. For low fertilization, better turf quality started at 4 WAIT, with a global increase of 1.3. Turf color was enhanced at 8 WAIT, and from 16 to 24 WAIT for conventional fertilization, with a global improved average of 1.l. Under nutritional stress, a global average improvement of 1.8 was obtained throughout the experimental period. The treatment
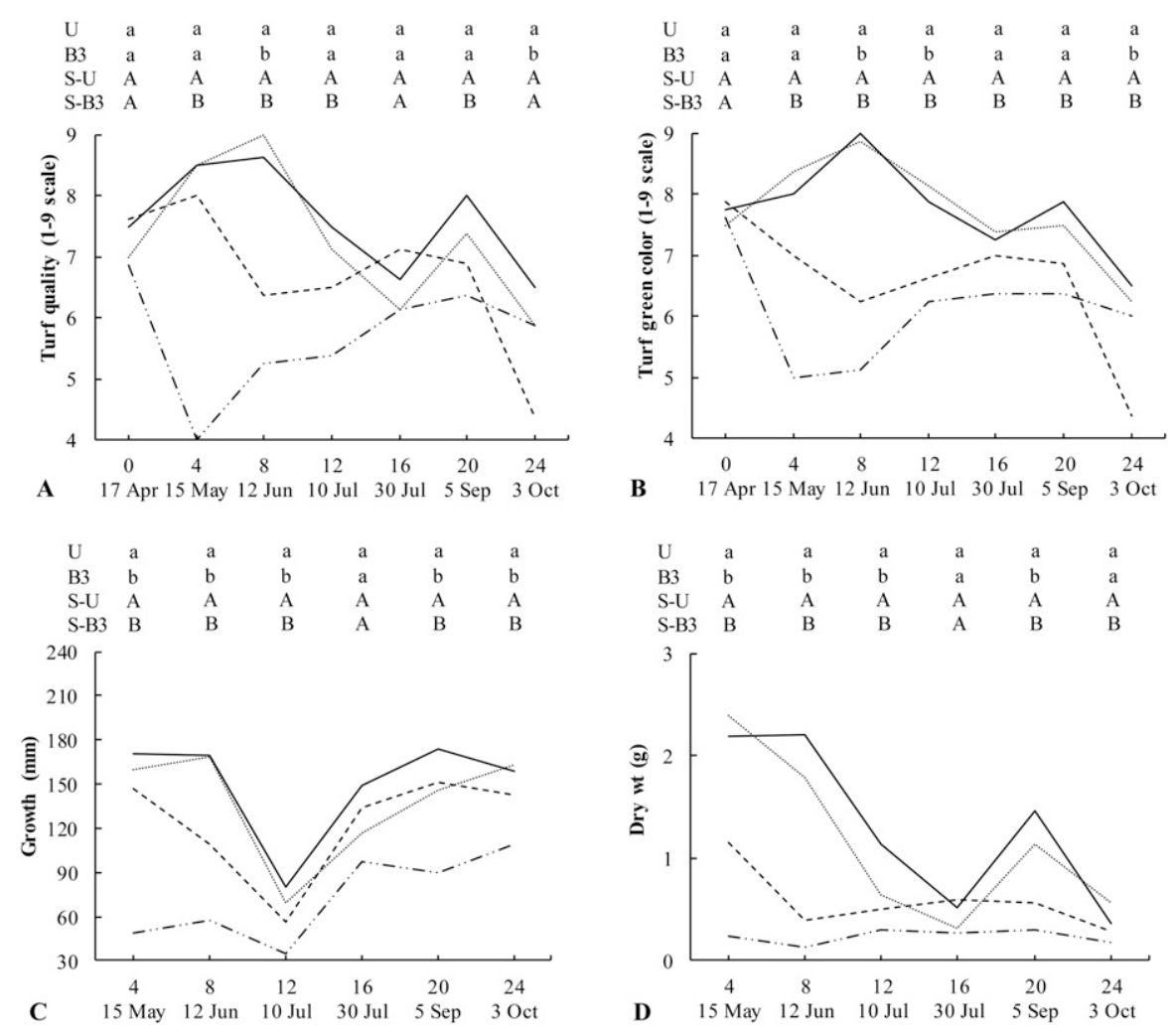

$$
\begin{aligned}
& \text { Dates } \\
& \text { _.... Stressed Untreated _..... Untreated … Stressed B3 _ B3 }
\end{aligned}
$$

Fig. 8. Visual quality and growth of perennial ryegrass treated twice in a 2 -week interval with the biostimulant 3 [B3 (Rizosan Eco; Biotecnología del Mediterráneo)] at $2.3 \mathrm{~mL}(0.08 \mathrm{floz})$ per pot in 2014 . The same letters above each evaluation date indicate nonsignificant differences according to Fisher's protected least significant difference test $(P<0.05)$ to identify significant differences among means for treatment effect. Stressed untreated (S-U): low fertilization program without $B 3$ treatment. Untreated (U): conventional fertilization program without B3 treatment. Stressed B3 (S-B3): low fertilization program with B3 biostimulant treatment. B3: conventional fertilization program with B3 biostimulant treatment. Graphics A, B, C, and D include the analysis fixing fertilization factor (uppercase letters for nutritional stress and lowercase letters for conventional fertilization); turf quality ( $1=$ dead turf, $9=$ maximum quality); turf color $(1=$ light-green turf, $9=$ dark-green turf); $1 \mathrm{~mm}=0.0394$ inch; $1 \mathrm{~g}=0.0353 \mathrm{oz}$.

factor was significant in 2013 for turf growth $(P<0.01)$ and clippings' dry weight $(P<0.01)$. The B3 treatment led to $20.6 \%$ growth and $62.3 \%$ clippings' dry weight increments (Fig. 7C and D). In 2014, three-way interactions were detected for all the assessments. As a result, the statistical analysis was conducted again by fixing the fertilizing factor (Fig. 8). Turf quality and color increased after the B3 treatment (Fig. 8A and B) and became more evident under nutritional stress ( 1.7 for both assessments) than for conventional fertilization ( 0.8 for turf quality and 1.1 for turf color). Similarly, turf growth and clippings' dry weight (Fig. 8C and
D) also improved with the B3 treatment, with $23.0 \%$ and $125.9 \%$ for conventional fertilization, and $87.4 \%$ and $391.3 \%$ for low fertilization, both respectively. For 2013-14, the B3treated turf generally showed better quality, a darker green color, and more growth and clipping yield than the untreated turf. We are not certain about the extent to which the B3 effect was due to either amino acid content or other compounds in the mixture. Kauffman et al. (2007) reported beneficial effects for a foliar amino acid-based biostimulant on perennial ryegrass under heat stress, which suggests that amino acids are advantageous under abiotic stresses, 
and/or an an application (foliar) method is likewise gainful. Mahdavi et al. (2017) also reported that the average performance ratings on perennial ryegrass treated with amino acid glycine betaine were significantly higher than in the untreated controls. This beneficial effect cannot be explained by the presence of exogenous microorganisms as in $\mathrm{Bl}$ and B2. The biostimulant herein employed (B3) did not contain $\mathrm{N}_{2}$ fixing microorganisms - rather $\mathrm{N}$, micronutrients, polysaccharides, and free amino acids. The total $\mathrm{N}$ applied with the $\mathrm{B} 3$ biostimulant throughout the experiment was only $1.2 \mathrm{~g} \cdot \mathrm{m}^{-2}$, while $\mathrm{N}$ reduction from the conventional to the stressed program was $39.2 \mathrm{~g} \cdot \mathrm{m}^{-2}$ (50.4 vs. $11.2 \mathrm{~g} \cdot \mathrm{m}^{-2}$, respectively). Therefore, the improvement observed for the B3-treated stressed turf can be associated with the combination of all the compounds in the mixture, rather than with the $\mathrm{B} 3 \mathrm{~N}$ content.

The benefits observed for perennial ryegrass during the study were obtained under greenhouse conditions and using high biostimulant doses. The application procedure is critical, and it is strongly dependent on the application dose, the timing of applications, and other untested factors, such as soil nutritional status or application type (soil vs. foliar). Integration with turf management practices (mowing, irrigation, etc.) could also be decisive for turfgrass quality and growth. Despite these determining factors, the overall conclusion of this study is that the tested biostimulants increased turfgrass quality despite the reduction in mineral fertilization. In fact, biostimulants' response was more marked under nutritional stress, which entails the possibility of reducing mineral fertilization. The results herein reported show that these biostimulants are a useful tool for high-input turfgrass management, which could greatly benefit the environment. Nevertheless, it is necessary to conduct field studies to validate these preliminary findings.

\section{Literature cited}

Aamlid, T.S. and H.M. Hanslin. 2009. Evaluation of organic fertilizers and biostimulants on sand-based golf greens and football pitches under Scandinavian climate conditions. Intl. Turfgrass Soc. Res. J. 11: 919-931.

Aamlid, T.S., A. Kvalbein, and T. Pettersen. 2017. Evaluation of an amino-acid-based fertilizer for grow-in of creeping bentgrass putting greens. Crop Sci. 57:1-4.

Acikgoz, E., U. Bilgili, F. Sahin, and K. Guillard. 2016. Effect of plant growthpromoting Bacillus sp. on color and clipping yield of three turfgrass species. J. Plant Nutr. 39:1404-1411.

Battacharyya, D., M.Z. Babgohari, P. Rathor, and B. Prithiviraj. 2015. Seaweed extracts as biostimulants in horticulture. Scientia Hort. 196:39-48.

Botta, A. 2013. Enhancing plant tolerance to temperature stress with amino acids: An approach to their mode of action. Acta Hort. 1009:29-36.

Brown, P. and S. Saa. 2015. Biostimulants in agriculture. Front. Plant Sci. 6:671.

Butler, T., M. Purcell, and A. Hunter. 2007. Microbial inoculant and biostimulant impact on turfgrass growth, morphology and stress tolerance when applied pre-germination. Acta Hort. 762:55-61.

Butler, T., K. Mwabadaba, and A. Hunter. 2012. The influence of biostimulants on nutrient leaching from a USGA golf green during the grow-in year. Acta Hort. 938:161-167.

Calvo, P., L. Nelson, and J.W. Kloepper. 2014. Agricultural uses of plant biostimulants. Plant Soil 383:3-41.

Canellas, L.P., F.L. Olivares, N.O. Aguiar, D.L. Jones, A. Nebbioso, P. Mazzei, and A. Piccolo. 2015. Humic and fulvic acids as biostimulants in horticulture. Scientia Hort. 196:15-27.

Christians, N.E., D.P. Martin, and J.F. Wilkinson. 1979. Nitrogen, phosphorus, and potassium effects on quality and growth of kentucky bluegrass and creeping bentgrass. Agron. J. 71:564-567.

Colla, G., S. Nardi, M. Cardarelli, A. Ertani, L. Lucini, R. Canaguier, and Y. Rouphael. 2015. Protein hydrolysates as biostimulants in horticulture. Scientia Hort. 96:28-38.

Colla, G., L. Hoagland, M. Ruzzi, M. Cardarelli, P. Bonini, R. Canaguier, and Y. Rouphael. 2017. Biostimulant action of protein hydrolysates: Unraveling their effects on plant physiology and microbiome. Front. Plant Sci. 8:2202.

Delić, D., O. Stajković-Srbinović, D. Kuzmanović, N. Rasulić, S. Maksimović, J. Radović, and A. Simić. 2013. Influence of plant growth promoting rhizobacteria on alfalfa, Medicago sativa L. yield by inoculation of a preceding italian ryegrass,
Lolium multiflorum Lam., p. 333-339. In: S. Barth and D. Milbourne (eds.). Breeding strategies for sustainable forage and turf grass improvement. Springer, Dordrecht, The Netherlands.

du Jardin, P. 2015. Plant biostimulants: Definition, concept, main categories and regulation. Scientia Hort. 196:3-14.

Duncan, R.R. and R.N. Carrow. 1999. Turfgrass molecular genetic improvement for abiotic/edaphic stress resistance. Adv. Agron. 67:233-305.

Ehaliotis, C., K. Papadopoulou, M. Kotsou, I. Mari, and C. Balis. 1999. Adaptation and population dynamics of Azotobacter vinelandii during aerobic biological treatment of olive-mill wastewater. FEMS Microbiol. Ecol. 30:301-311.

Elliot, M.L. and M. Prevatte. 1996. Response of tifdwarf bermudagrass to seaweed-derived biostimulants. HortTechnology 6:261-263.

European Union. 1991. Directive 1991/ $676 /$ EEC of the Council directive of 12 December 1991 concerning the protection of waters against pollution caused by nitrates from agricultural sources. Official J. European Communities L375:1-8.

European Union. 2009. Directive 2009/ 128/EC of the European Parliament and of the Council of 21 October 2009 establishing a framework for community action to achieve the sustainable use of pesticides. Official J. European Union L309:71-86.

Guo, R., C. Nendel, C. Rahn, C. Jiang, and Q. Chen. 2010. Tracking nitrogen losses in a greenhouse crop rotation experiment in north China using the EURotate $\mathrm{N}$ simulation model. Environ. Pollut. 158:2218-2229.

Hu, L., T. Hu, X. Zhang, H. Pang, and J. Fu. 2012. Exogenous glycine betaine ameliorates adverse effects of salt stress on perennial ryegrass. J. Amer. Soc. Hort. Sci. 137:38-46.

Jiang, Y. and B. Huang. 2001. Physiological responses to heat and stress alone or in combination with drought: A comparison between tall fescue and perennial ryegrass. HortScience 34:682-686.

Karnock, K.J. 2000. Promises, promises: Can biostimulants deliver? Golf Course Mgt. 68(8):67-71.

Kauffman, G.L., D.P. Kneivel, and T.L. Watschke. 2007. Effects of a biostimulant on the heat tolerance associated with photosynthetic capacity, membrane thermostability, and polyphenol production of perennial ryegrass. Crop Sci. 47:261267.

Krishnan, S., K. Laskowski, V. Shukla, and E.B. Merewitz. 2013. Mitigation of 
drought stress damage by exogenous application of a non-protein amino acid $\gamma$-aminobutyric acid on perennial ryegrass. J. Amer. Soc. Hort. Sci. 138:358366.

López-Bucio, J., R. Pelagio-Flores, and A. Herrera-Estrella. 2015. Trichoderma as biostimulant: Exploiting the multilevel properties of a plant beneficial fungus. Scientia Hort. 196:109-123.

Mahdavi, S., M. Kafi, E. Fallahi, M. Shokrpour, and L. Tabrizi. 2017. Drought and biostimulant impacts on mineral nutrients, ambient and reflected light-based chlorophyll index, and performance of perennial ryegrass. J. Plant Nutr. 40:22482258.

Morris, K.N. and R.C. Shearman. 1998. NTEP turfgrass evaluation guidelines, $\mathrm{p}$. 1-5. In: NTEP Turfgrass Evaluation Wkshp. Natl. Turfgrass Evaluation Program, Beltsville, MD.

Mueller, S.R. and W.R. Kussow. 2005. Biostimulants influences on turfgrass microbial communities and creeping bentgrass putting green quality. HortScience 40:1904-1910.

Neeteson, J.J. and O.T. Carton. 2001. The environmental impact of nitrogen in field vegetable production. In international conference on environmental problems associated with nitrogen fertilisation of field grown vegetable crops. Acta Hort. 563:21-28.

Podile, A.R. and A.K. Kishore. 2007. Plant growth-promoting rhizobacteria, p. 195-230. In: S.S. Gnanamanickam (ed.). Plant-associated bacteria. Springer, Dordrecht, The Netherlands.
Ramos, C., A. Agut, and A.L. Lidon. 2002. Nitrate leaching in important crops of the Valencian Community region (Spain). Environ. Pollut. 118:215-223.

Rouphael, Y., P. Franken, C. Schneider, D. Schwarz, M. Giovanetti, M. Agnolucci, S. De Pascale, P. Bonini, and G. Colla. 2015. Arbuscular mycorrhizal fungi act as biostimulants in horticultural crops. Scientia Hort. 196:91-108.

Ruzzi, M. and R. Aroca. 2015. Plant growth-promoting rhizobacteria act as biostimulants in horticulture. Scientia Hort. 196:124-134.

Sahin, F. and M. Turan. 2013. Use of plant growth promoting rhizobacteria PGPR to improve effectiveness of chemical fertilizers on spring wheat and barley in the field condition. 48th Croatian and 8th Intl. Symp. Agr., 17-22 Feb. 2013, Dubrovnik, Croatia. p. 4.

Stiegler, J.C., M.D. Richardson, and D.E. Karcher. 2013. Foliar absorption of various inorganic and organic nitrogen sources by creeping bentgrass. Crop Sci. 53:1148-1152.

Sun, S., M. An, L. Han, and S. Yin. 2015. Foliar application of 24-epibrassinolide improved salt tolerance of perennial ryegrass. HortScience 50:1518-1523.

Van Oosten, M.J., O. Pepe, S. De Pascale, S. Silletti, and A. Maggio. 2017. The role of biostimulants and bioeffectors as alleviators of abiotic stress in crop plants. Chem. Biol. Technol. Agr. 4:5.

Wu, Y.-Y., Q.-J. Chen, M. Chen, J. Chen, and X.-C. Wang. 2005. Salt-tolerant transgenic perennial ryegrass (Lolium perenne L.) obtained by Agrobacterium tumefaciens-mediated transformation of the vacuolar $\mathrm{Na}^{+} / \mathrm{H}^{+}$antiporter gene. Plant Sci. 169:65-73.
Wu, W., Q. Zhang, E.H. Ervin, Z. Yang, and X. Zhang. 2017. Physiological mechanism of enhancing salt tolerance of perennial ryegrass by 24 -epibrassinolide. Front. Plant Sci. 8:1017.

Xu, Y. and B. Huang. 2010. Responses of creeping bentgrass to trinexapac-ethyl and biostimulants under summer stress. HortScience 45:125-131.

Yadav, A.N., P. Verma, B. Singh, V.S. Chauahan, A. Suman, and A.K. Saxena. 2017. Plant growth promoting bacteria: Biodiversity and multifunctional attributes for sustainable agriculture. Adv. Biotechnol. Microbiol. 5:1-16.

Zhang, X., E.H. Ervin, and R.E. Schmidt. 2003a. Seaweed extract, humic acid, and propiconazole improve tall fescue sod heat tolerance and posttransplant quality. HortScience 38:440-443.

Zhang, X., E.H. Ervin, and R.E. Schmidt. 2003b. Physiological effects of liquid applications of a seaweed extract and a humic acid on creeping bentgrass. J. Amer. Soc. Hort. Sci. 128:492-496.

Zhang, X. and E.H. Ervin. 2008. Impact of seaweed extract-based cytokinins and zeatin riboside on creeping bentgrass heat tolerance. Crop Sci. 48:364-370.

Zhang, X., W. Liu, M. Schloter, G. Zhang, Q. Chen, J. Huang, L. Li, J.J. Elser, and X. Han. 2013a. Response of the abundance of key soil microbial nitrogencycling genes to multi-factorial global changes. PLoS One 8:e76500.

Zhang, X., P. Summer, and E.H. Ervin. 2013b. Foliar amino acid-based fertilizer impact on creeping bentgrass drought resistance. Intl. Turfgrass Soc. Res. J. $12: 1-7$. 